\title{
Pracuje w korytarzu, pisze po ścianach, a kąpiel bierze wśród kwiatów, czyli obrazy mieszkań konsumentów w przekazie magazynów wnętrzarskich
}

DOI: 10.19195/2083-7763.9.10

\section{Wprowadzenie}

Konsumpcja, rozumiana jako „forma komunikacji z grupą, podtrzymywanie wspólnot wyobrażonych, ale także wyznacznik statusu społecznego, szczególnie pozycji klasowej"1, jest ważnym (o ile nie najważniejszym) aspektem życia zamożnych społeczeństw. Jedną z kluczowych przestrzeni działań konsumpcyjnych jest mieszkanie. Zamieszkiwana przestrzeń musi realizować wiele „pozamieszkalnych” funkcji: ma obrazować miejsce jednostki w hierarchii społecznej, definiować jej przynależność grupową, przedstawiać wartości, którymi się kieruje, i cele, do których dąży ${ }^{2}$. Te stawiane przed współczesnym mieszkaniem zadania są osią tematyczną niniejszego opracowania. Wybrane aspekty tworzenia wizerunków przestrzeni mieszkalnych przedstawię na przykładzie magazynów lifestylowych — ważnych drogowskazów, podpowiadających, jak żyć zgodnie z wymogami społeczeństwa konsumentów ${ }^{3}$. Przedmiotem przeprowadzonych analiz są prezentacje mieszkań zamieszczone w czasopiśmie wnętrzarskim „M jak Mieszkanie” (dalej: MjM). Analizą objęłam wydania od stycznia do czerwca 2015 roku. Półrocze to zostało

${ }^{1}$ J. Bielecka-Prus, Wycieczka po pokoju nastolatki: praktyki prezentacji przestrzeni prywatnej $w$ wideoblogach, [w:] Socjologia zamieszkiwania, red. M. Łukasiuk, M. Jewdokimow, Warszawa 2014, s. 127; zob. np. A. Giddens, Nowoczesność i tożsamość, przeł. A. Szulżycka, Warszawa 2010.

2 Zob. M. Jacyno, Mieszkanie i „moralna architektura” kultury indywidualizmu, [w:] Co to znaczy mieszkać. Szkice antropologiczne, red. G. Woroniecka, Warszawa 2007.

${ }^{3}$ Jak zauważa Małgorzata Jacyno, nie chodzi tylko o „pławienie się w konsumpcji, ale także o konieczność uczynienia z konsumpcji konsumenckich wyborów” — ibidem, s. 40. 
wskazane drogą losowania - brałam pod uwagę ostatnie pięć lat wydawania periodyku (lata 2014-2018). Ogółem materiał empiryczny tworzą 32 prezentacje mieszkań - są to wyłącznie wnętrza realnie istniejące i użytkowane ${ }^{4}$.

Wybrałam do analizy magazyn z niższej półki cenowej. Głównym powodem była jego społeczna dostępność - zależało mi na obrazach mieszkań dostępnych jak najszerszej grupie odbiorców ${ }^{5}$. Jestem jednak świadoma, że nawet tak zdefiniowany materiał badawczy ma swoje ograniczenia. Odbiorcy magazynów wnętrzarskich są ściśle określeni - są one skierowane do ludzi o rozwiniętych możliwościach konsumpcyjnych, świadomych, że ich mieszkanie jest ważnym aspektem budowanego wizerunku społecznego. Nie można na przykład na stronach tychże magazynów zobaczyć odbicia norm i wartości grup społecznych z różnych względów nierealizujących lub ograniczających stosowanie praktyk konsumpcyjnych. Jednak mimo tych zastrzeżeń pisma o wnętrzach są interesującym materiałem empirycznym dla socjologa - między innymi dlatego, że są zwierciadłem norm obowiązujących członków społeczeństwa konsumpcyjnego. Lektura tych tytułów pozwala określić wzór konsumenta - jego preferencje, potrzeby, otoczenie społeczne.

Czasopisma wnętrzarskie są skierowane do właścicieli mieszkań estetycznych ${ }^{6}$ - mieszkańców dużych miast, w średnim wieku, zarabiających w okolicach średniej krajowej i wyżej, którzy nie tylko chcą i mogą, ale nawet muszą „odpowiednio" mieszkać. Dlatego też periodyki te pełnią rolę wzorcotwórczą, kształtującą

${ }^{4} \mathrm{~W}$ analizach pominęłam stylizacje wnętrz przygotowywane przez redaktorki pisma $\mathrm{w}$ celu zaprezentowania nowych lub sezonowych (związanych z porą roku czy świętami) trendów wnętrzarskich.

${ }^{5}$ Comiesięczny nakład czasopisma „M jak Mieszkanie” wynosi średnio około 90 tys., a cena egzemplarza w momencie pisania artykułu wynosiła 5,99 zl, co plasuje tytuł na drugim miejscu pod względem wielkości nakładu — za tańszym czasopismem „Moje Mieszkanie” (nakład 101 tys., cena egzemplarza: 3,99 zf), za: https://www.wirtualnemedia.pl/artykul/sprzedaz-pism-wnetrzarskichpazdziernik-2017-m-jak-mieszkanie-wyprzedzilo-cztery-katy (dostęp: 6.10.2018).

6 Termin „mieszkanie estetyczne” zostało zaczerpnięte z prac Grażyny Woronieckiej oraz Doroty Rancew-Sikory. Pierwsza z nich, pisząc we wstępie do zredagowanej przez siebie publikacji Co znaczy mieszkać. Szkice antropologiczne o zawartych w książce badaniach socjologicznych, następująco scharakteryzowała badanych: „mieszkańcy miast o znacznej skłonności do refleksyjności, traktują swoje życie jako szansę na ekspresję i autokreację, a mieszkanie jako jedno z pól ich działania" - G. Woroniecka, Wstęp. Co to znaczy mieszkać, [w:] Co to znaczy mieszkać. Szkice antropologiczne, red. G. Woroniecka, Warszawa 2007, s. 17. Takich właśnie świadomych istoty swych działaniach konsumpcyjnych aktorów, chcących zamanifestować siebie za pomocą swego najbliższego otoczenia, znalazłam w mieszkaniach prezentowanych w magazynach wnętrzarskich. $\mathrm{W}$ artykule drugiej ze wspomnianych autorek, w tym samym tomie, pojawia się pojęcie domu estetycznego, użytego na określenie praktyk zamieszkiwania wyłaniających się z analizy czasopisma wnętrzarskiego „Cztery Kąty” - D. Rancew-Sikora, Dom estetyczny jako dom indywidualny, [w:] Co to znaczy mieszkać... 
i ukierunkowującą działania konsumenckie nie tylko osób o wysokiej pozycji społecznej, lecz także tych, którzy do takiej pozycji aspirują ${ }^{7}$.

\section{Wizytówka — opowieść o konsumentach}

Jak przyznają przedstawiciele różnych dyscyplin naukowych (psychologowie, lingwiści, socjologowie czy historycy), tworzenie opowieści o własnym życiu jest ważną społecznie, porządkującą rzeczywistość praktyką:

Schematy narracyjne, czyli schematy mające strukturę opowieści o przebiegu pewnych zdarzeń oraz o zachowaniach, intencjach, uczuciach ich uczestników, są powszechnie stosowaną przez ludzi formą reprezentacji wiedzy o zjawiskach i podmiotach życia społecznego, wywierającą wpływ na sposób zapamiętania, rozumienia i wykorzystania tej wiedzy we własnym działaniu ${ }^{8}$.

Opowieści pełnią także inne funkcje - są niezbędne w orientowaniu się $\mathrm{w}$ przesyconej informacjami rzeczywistości:

Ludzie uwielbiają dobre opowieści. Odbiorcy wiedzą, na którą partię powinni zagłosować w najbliższych wyborach [...], w jakim kraju czy mieście chcieliby spędzić wakacje [...], jaką sieć telefonii komórkowej i jaki komputer wybrać [...]. Dobra opowieść sprawia, że zmieniamy percepcję osoby, miejsca, firmy, partii, stowarzyszenia, regionu, kraju? .

Siła opowieści jest także wykorzystywana do tworzenia konsumenckich pragnień i wskazywania sposobów ich realizacji:

Historie nie są niewinne. Mogą służyć różnym celom - mogą wykorzystywać nasze emocje i wzruszenia, by nakłonić nas do zakupu rzeczy, której nie potrzebujemy, albo podjęcia działania, którego nigdy nie mieliśmy zamiaru podejmować. Mogą rozbudzać w nas potrzeby, by potem podsuwać produkty, które mają je zaspokoić ${ }^{10}$.

${ }^{7}$ Choć zagadnienie to wykracza poza temat poniższego opracowania, warto wspomnieć, że analiza czasopism o wnętrzach pozwala przyjrzeć się trudno uchwytnemu badawczo zjawisku - modzie wnętrzarskiej. Analiza tych periodyków daje dostęp do wiedzy, której uzyskanie w badaniach bezpośrednich byłoby trudne. Jak pokazują studia nad modą we wnętrzu autorstwa Bogny Dowgiałło, określenie swojego mieszkania jako modnego nie jest społecznie akceptowane — „ludzie mają przeświadczenie, że ich gust nie jest kształtowany przez modę - przeciwnie - jest od niej niezależny" - eadem, Moda w mieszkaniu, [w:] Co to znaczy mieszkać..., s. 114. Z zebranych przez Dowgiałło wywiadów wynika, że nikt nie chce być właścicielem modnej kanapy, tapety czy wanny i „trzeba być wariatem albo jakimś bogatym snobem, żeby gonić za modą. (wyw.)” (ibidem, s. 116). Jednak analiza magazynów wnętrzarskich oraz porównanie ich treści z zasobami na temat mieszkań (blogi i fora internetowe) dostępnymi w sieci pozwala nie tylko stwierdzić, że ludzie chętnie poddają się wnętrzarskim modom, lecz także prześledzić dynamikę kształtowania się tych mód.

${ }^{8}$ K. Stemplewska-Żakowicz, Koncepcje narracyjnej tożsamości. Od historii życia do dialogowego „ja”, [w:] Narracja jako sposób rozumienia świata, red. J. Trzebiński, Gdańsk 2002, s. 83.

${ }^{9}$ E. Mistewicz, Marketing narracyjny. Jak budować historie, które sprzedają, Gliwice 2011, s. 43.

10 A. Piwowarska, Autentyczność przyciaga. Jak budować swoja markę na prawdziwym i porywajacym przekazie?, Gliwice 2015, s. 175. 
Tkanie opowieści jest też kluczowym elementem przekazu analizowanego czasopisma. W MjM ważne są nie tyle konkretne wskazówki co do wyboru mebli i kolorystyki we wnętrzu, ile właśnie prowadzona (najlepiej niecodzienna i zaskakująca) opowieść. Tę narracyjność przekazu omówię na przykładzie ważnej części każdego z analizowanych z artykułów - wizytówki przedstawiającej pokrótce sylwetkę gospodarzy mieszkań. Jest to krótki tekst, często ze zdjęciem, wizualnie wyróżniony (ramka), sformatowany większą i odmienną czcionką niż tekst główny ${ }^{11}$. Wizytówki nie są na ogół związane z tematem czasopisma - urządzaniem mieszkania. Kilka zdań o bohaterach artykułów ma za zadanie przede wszystkim uwiarygodniać gospodarzy jako rzetelnych (w znaczeniu: realizujących wzory społeczeństwa konsumpcyjnego) konsumentów. Dlatego też treść wizytówek dotyczy przede wszystkim sposobów spędzania czasu wolnego, wśród których wyróżniane są przez redakcję kategorie: sport, podróże i gotowanie ${ }^{12}$. Akcentowane działania wpisują się w konstruowany w dyskursie dominującym kulturowy wizerunek przedstawicieli klasy średniej: „Troska o ciało, zabiegi odmładzające, kulinaria, ogród i aranżacja wnętrz - to treści i zakres promowanej autokonstrukcji jednostki, pośrednio wskazującej na to, gdzie dokonuje się proces indywidualizacji i jaki styl życia pozwala na zakwalifikowanie siebie do klasy średniej”" ${ }^{\prime 3}$. Na kolejnych stronach niniejszego opracowania szczegółowo scharakteryzuję wskazane w wizytówkach cechy mieszkańców mieszkań estetycznych.

\section{Lubi gotować i podróżować 14}

Spędzanie wolnego czasu na przygotowywaniu i spożywaniu potraw (najlepiej egzotycznych lub dietetycznych) to istotny aspekt praktykowania konsumpcji w społeczeństwie konsumentów. Anna Wieczorkiewicz, analizując inny wątek konsumenckiego systemu eksperckiego — programy kulinarne, zauważa:

Jedzenie rozumiane jako czynność zaspokajania głodu często usuwa się na drugi plan, ustępując znakowym aspektom jedzenia, nakierowanym na inne obszary życia. [...]. Gotowanie to nie

11 Określam wizytówkę mianem komunikatu wizualnego, ponieważ ze względu na swe uproszczenie i estetyzację należy on do oglądanej części przekazu - podobnie jak tytuł artykułu, lid i wszelkie śródtytuły, zob. T. Piekot, Dyskurs wiadomości prasowych, Kraków 2006.

12 Warto zauważyć, że w ciągu dekady nastąpiła istotna zmiana narracyjna w treści omawianej wizytówki. Jeszcze w 2007 roku tę część artykułu Maciej Brosz opisywał następująco: „Wspomniana metryczka obejmuje na ogół skąpe informacje: jaki zawód wykonuje właściciel, jak długo trwał remont, gdzie zlokalizowane jest mieszkanie - przystosowanie mieszkania do użycia, jaki był jego koszt" M. Brosz, (Za)mieszk(iw)anie. Przestrzeń konstruowana, [w:] Co to znaczy mieszkać..., s. 75.

${ }^{13}$ M. Jacyno, op. cit., s. 40.

${ }^{14} \mathrm{MjM}, \mathrm{nr}$ 5, s. 75. 
tylko przygotowywanie posiłków dla rodziny — to także przygoda, przyjemność, hobby, działanie poznawcze, czynność towarzyska $[\ldots]^{15}$.

W analizowanym materiale wątek kulinarny prowadzony jest przez nadawcę dwutorowo. Po pierwsze, redakcja przedstawia bohaterów artykułów w kontekście (rodzinnego i towarzyskiego) celebrowania jedzenia:

Jest wyśmienitym kucharzem, kultywującym rodzime tradycje kulinarne. (nr 6, s. 22)

W mieszkaniu często przyjmuje rodzinę i przyjaciół, częstując ich przyrządzonymi przez siebie daniami. (nr 5, s. 33)

Po drugie, kładzie nacisk na umiejętność przygotowania fantazyjnych potraw:

Jest specjalistą od przyrządzania deserów, zwłaszcza z czekoladą. (nr 5, s. 75)

Specjalistka od zupy tajskiej, kremu brokułowo-marchewkowego, dań jednogarnkowych i koktajli. (nr 6, s. 82)

Innym ważnym obszarem konsumenckiego realizowania się klasy średniej jest podróżowanie: „W płynnym stadium nowoczesności osiadła większość rządzona jest przez wędrującą i eksterytorialną elitę" ${ }^{16}$. Im częstsza, dalsza i bardziej ekskluzywna podróż, tym lepiej dla społecznego wizerunku konsumenta. Analizowane czasopismo starannie odzwierciedla ten wymóg współczesności. Akcentowane przez MjM podróżowanie nie jest czynnością, która może odbywać się w dowolnym kierunku. Redakcja kładzie nacisk na zrealizowane lub planowane podróże zagraniczne bohaterów - do miejsc egzotycznych lub elitarnych, niedostępnych przeciętnemu czytelnikowi MjM i przez to prezentujących wysoką pozycję społeczną bohaterów:

Magda uwielbia podróże do dalekich, egzotycznych krajów. Zwykle ona i jej mąż organizują je sami, starając się unikać utartych turystycznych szlaków [...]. (nr 6, s. 52)

Kochają podróże oraz kuchnię azjatycką. W tym roku planują wypad na Mauritius. (nr 4, s. 84)

Uwielbia podróżować po świecie, a szczególnie upodobała sobie Berlin i Kalifornię, gdzie surfuje po falach oceanu. (nr 6, s. 49)

\section{Z pasją ćwiczy jogę oraz jeździ konno ${ }^{17}$}

Zygmunt Bauman, charakteryzując społeczeństwo konsumentów, podkreśla kulturową istotność zdrowego i sprawnego ciała - tylko takie ciało pozwala na właściwą realizację „pełnego i prawdziwego” życia: „Zdrowie i sprawność fizyczną uznaje

${ }^{15}$ A. Wieczorkiewicz, O wyobraźni kulinarnej i aporii jedzenia. Kultura uwikłana w konsumpcję, [w:] Terytoria smaku. Studia $z$ antropologii i socjologii jedzenia, red. U. Jarecka, A. Wieczorkiewicz, Warszawa 2014, s. 251.

16 Z. Bauman, Płynna nowoczesność, przeł. T. Kunz, Kraków 2006, s. 22.

17 MjM, nr 5, s. 33. 
się często za zbieżne i synonimiczne. Oba dotyczą przecież troski o ciało, stanu, w jakim pragnęlibyśmy je zachować, oraz trybu życia, którego powinien przestrzegać posiadacz ciała, aby spełnić swoje pragnienie"18. Sprawne ciało gwarantuje gotowość do realizacji wyzwań świata konsumpcji, umożliwia pełne w nim uczestniczenie. Większość bohaterów artykułów, poza dwiema osobami, które „w czasie wolnym czytają książki”, jest przedstawiana przez pryzmat ich fizycznej aktywności:

Oboje preferują zdrowy styl życia i aktywne formy spędzania wolnego czasu. (nr 3, s. 51)

Od zawsze fascynowała się ruchem i sportem. Była gimnastyczką sportową i zawodową tancerką [...]. (nr 6, s. 49)

Lubi ruch i adrenalinę: trenuje crossfit, jeździ na motocyklu enduro, a zimą szusuje z rodziną na stokach. (nr 3, s. 99)

Żeglowanie to nasz ulubiony sposób na wypoczynek. (nr 8, s. 65)

Sport stanowi ważny element charakterystyki właścicieli, nawet jeśli aktywność ta jest okazjonalna (urlopowa):

Urlopy spędza aktywnie: jeździ na rowerze, na nartach, nurkuje. (nr 2, s. 52)

Na urlop wyjeżdża tam, gdzie można szybko jeździć na nartach. (nr 1, s. 53)

Dobrze jest, jeśli uprawiany sport należy do elitarnych lub nietypowych nurkowanie, gimnastyka sportowa, żeglowanie czy taniec „wywodzący się z amerykańskiego jazzu”. Jeśli bohaterowie artykułu dążą do sprawności w sposób bardziej dostępny, zwyczajny (jazda na nartach, na rowerze, bieganie), redakcja dodaje informację, która nadaje wyjątkowości przekazywanej treści:

Lubią wspólnie szusować na nartach, najlepiej w szwajcarskim Laax albo francuskim Auron. W przyszłości chcą wziąć udział w heliskiing w Kanadzie (ekstremalne narciarstwo poza uczęszczanymi trasami zjazdowymi). (nr 2, s. 35)

Oboje lubią bieganie i spacery z przygarniętym ze schroniska psem Edim. (nr 4, s. 54)

Zapalony rowerzysta, który po mieście śmiga na dwóch kółkach między samochodami także wtedy, gdy jedzie na spotkania z klientami. ( $\mathrm{nr} 3$, s. 35)

\section{Jest urzędnikiem ${ }^{19}$}

Zamykając wątek legitymizowania gospodarzy mieszkań jako wiarygodnych konsumentów, chcę zwrócić uwagę na wielką nieobecną analizowanych narracji pracę zarobkową. Praca, będąca najważniejszym, rozstrzygającym elementem tożsamości nowoczesnej, w późnej nowoczesności ustępuje miejsca samorealizowaniu

\footnotetext{
18 Z. Bauman, op. cit., s. 119.

${ }^{19} \mathrm{MjM}, \mathrm{nr}$ 6, s. 22.
} 
się w czasie wolnym ${ }^{20}$. Dlatego też wykonywanej przez bohaterów artykułów pracy redakcja MjM nie poświęca wiele miejsca - wątek zawodowy, poza wskazaniem w wizytówce, nie jest rozwijany w samych artykułach. Nadawca zdawkowo i bez charakterystycznej dla siebie emfazy (typu „pasjami czyta”) informuje czytelnika o zawodach właścicieli prezentowanych mieszkań:

Pracuje jako fotoedytor w jednym z dzienników. (nr 1, s. 84)

Basia pracuje w firmie ubezpieczeniowej. ( $\mathrm{nr} \mathrm{1,} \mathrm{s.} \mathrm{53)}$

Z wykształcenia architekt. (nr 6, s. 82)

Irena jest prawnikiem w niemieckiej kancelarii, a Maciek prowadzi agencję PR-owo-marketingową. (nr 2, s. 35)

Tylko w trzech przypadkach dziennikarki magazynu podkreślają emocjonalne zaangażowanie bohaterów artykułów w wykonywaną pracę:

Pracuje jako charakteryzatorka i kocha swój zawód. (nr 6, s. 101)

Zawodowo spełnia się jako dyrektor marketingu i PR w firmie telekomunikacyjnej. (nr 4, s. 54)

[...] pracuje w branży motoryzacyjnej. Motoryzacja jest jego największą miłością, zaraz po Marysi. (nr 5, s. 75)

\section{Uwielbiam tę łazienkę — emocje w mieszkaniu estetycznym}

Badacze społeczeństwa konsumpcyjnego podkreślają, że wypełniające mieszkania konsumentów przedmioty dobierane są poprzez ich subiektywne, emocjonalne znaczenie: „Przestrzeń domowa jest zorganizowana w porządku normatywnym. Przedmioty nie są jedynie materialnymi obiektami, ale aktorzy społeczni, przypisując im określoną wartość, wiążą z nimi określone postawy i sposoby działania oraz definicje siebie"21. Także w analizowanym materiale badawczym wnętrza mieszkań przedstawiane są przede wszystkim przez opowieści o przedmiotach „emocjonalnie znaczących". Jak pisze redaktor naczelna MjM we wprowadzeniu do jednego z numerów: „Nasz dom to miejsce wspólnego spędzania czasu, budowania dobrego nastroju. [...] Planując wnętrze, myślimy o emocjach, a sposób, w który aranżujemy przestrzeń, też o tych emocjach świadczy" (nr 8, s. 4). Dlatego opisy mieszkań estetycznych to w dużej mierze opisy emocjonalnych stanów mieszkańców - tworzone na przykład za pomocą czasowników „uwielbiać”, „lubić”, „kochać”:

Uwielbiam tę łazienkę - wyznaje Dorota. I choć nie urządzała jej, by wywrzeć wrażenie na gościach, wszyscy odwiedzający podziwiają niezwykłą aranżację. (nr 1, s. 86)

Podest sprawdza się też jako siedzisko, uwielbiane przez jej gości. (nr 6, s. 49)

Właśnie za to lubię moją kuchnię. Jest spontaniczna jak ja. (nr 4, s. 107)

20 Zob. M. Jacyno, op. cit.

${ }^{21}$ J. Bielecka-Prus, op. cit., s. 125-126. 
Redakcja przyjmuje dwie strategie emocjonalnego opowiadania o mieszkaniach estetycznych. Pierwsza to wątek anegdotyczny: większość bohaterów dzieli się z czytelnikami szczegółową opowieścią o jakimś drobiazgu w mieszkaniu. Ta narracja jest budowana za pomocą opisów zaangażowania emocjonalnego właścicieli („jakoś mnie wypatrzył i zauroczył”, „zakochaliśmy się w niej”):

Drewniany konik został wypatrzony przez właścicielkę na targu staroci [...] Podobno był elementem dekoracji karuzeli w wesołym miasteczku pod Paryżem. - Jakoś mnie wypatrzył i zauroczył [...] - śmieje się Łucja. (nr 6, s. 38)

Zobaczyliśmy tę lampę w projekcie i się zakochaliśmy w niej. Wpisywała się w klimat wymarzonej kuchni - mówią Marysia i Maciek. - Gdy okazało się, że została wycofana ze sprzedaży, zaczęliśmy jej szukać w internecie. I znaleźliśmy. Sam klosz. Na aukcji w Holandii. (nr 5, s. 73)

Drugi wątek to opowieść o miejscach. Przedmioty sygnalizują emocjonalne przywiązanie domowników do miejsc obecnego lub przeszłego zamieszkania miasta, dzielnicy, rzadziej regionu. Te narracje relacjonowane są „zewnętrznie” przez redaktorki MjM, bez elementów bezpośrednich wypowiedzi mieszkańców:

Wzór z dzieciństwa. Folkowy charakter tej prostej sypialni nadaje tkanina z różanym wzorem użyta do obicia zagłówka, wzorowana na „tybycie” czyli tradycyjnym, góralskim materiale. Właścicielom kojarzy się z rodzinnymi stronami, bo takie róże zdobią ludowe spódnice i chusty kobiet na Podhalu. (nr 1, s. 55)

Kuchnia za obrazem. Na ścianie oddzielającej kuchnię od pokoju dziennego wisi grafika „Muranów” - ilustruje uwielbienie Bartka dla jego nowej dzielnicy. (nr 5, s. 34)

Jednak podkreślane przez redakcję emocje gospodarzy mieszkań estetycznych są powierzchowne, zatrzymują się na estetycznej fasadzie środowiska życia samego życia i wypełniających ich (emocjonalnych) doświadczeń nie dotykają. W konstruowanych przez MjM obrazach mieszkań nie ma prywatności, intymności. Magazyn nie opowiada nawet o osobistej przeszłości domowników - nie ma zdjęć rodzinnych, nie ma przedmiotów dziedziczonych po przodkach, nie ma mebli z poprzednich mieszkań. Nie ma przedmiotów „ryzykownych” stylistycznie, ważnych dla mieszkańców, ale wyłamujących się z przygotowanych przez projektantów wnętrz kompletnych w najmniejszych detalach wizjach mieszkania ${ }^{22}$. Na społeczną istotność osobistych drobiazgów i pamiątek zwróciła uwagę Marta Skowrońska w swych badaniach na temat społecznego konstruowania komfortu w przestrzeni mieszkalnej: „Mieszkanie pełne jest obiektów wyrażających nie tylko jednostkową tożsamość i sprawczość (własnoręcznie wykonane przedmioty, ślady doświadczeń), ale też więź z innymi ludźmi. Zdjęcia na półce materializują rodzinne wspomnienia, szalik "Lecha« łączy nas z innymi miłośnikami

22 O roli projektantów wnętrz jako twórców tożsamości (czy też może „tożsamości”) mieszkańców mieszkań estetycznych piszę w innym miejscu - zob. K. Biskupska, Mieszkanie wypełniło się światłem, czyli o (pozornej) wolności w mieszkaniu estetycznym, „Znaczenie. Kultura - komunikacja - społeczeństwo" 2015, nr 13, s. 19-30. 
tej drużyny (a dzieli z kibicami rywali) [..."”23. W analizowanym materiale metaforyczny „szalik Lecha” jest wielkim nieobecnym. W całym materiale jedynym stylistycznie „ryzykownym” elementem jest kolekcja „świętych obrazków i figurek. Część z nich Karolina dostała od babci. Nie mają dla niej wymiaru religijnego, ale lubi ich nieco kiczowatą stylistykę" (nr 6, s. 49). Jednak w tym przypadku opisany zbiór przedmiotów dopełnia, a nie przełamuje, odważną, awangardową stylistykę mieszkania.

\section{Ukryte kody prestiżu}

W opowieściach o przestrzeni mieszkania estetycznego można znaleźć dyskretnie zaznaczone atrybuty pozycji społecznej mieszkańców. Najważniejsze z nich to: akt własności i wielkość mieszkania, wykonane na zamówienie meble, posiadane dzieła sztuki (także sztuki użytkowej).

Historia mieszkania estetycznego rozpoczyna się w momencie zakupu lokalu (tylko jedno mieszkanie przeszło generalny remont po kilkunastu latach użytkowania przez tych samych właścicieli). Zwykle są to mieszkania nowe, w czterech przypadkach jest mowa o mieszkaniach z rynku wtórnego, ale są to mieszkania wyjątkowe, „z klimatem” - ulokowane w wielkomiejskich kamienicach w Warszawie i Katowicach. Wszystkie przedstawione w MjM lokale są własnością mieszkających w nich osób, choć sposób sfinansowania zakupu (środki własne czy kredyt) nie jest tematem poruszanym przez redakcję. Mieszkanie własnościowe jest niewątpliwie jasną wskazówką dotycząca zamożności gospodarzy. Ale nie tylko. Jest to również sygnał ze strony magazynu wnętrzarskiego, że mieszkanie estetyczne, którego wygląd odzwierciedla wymogi społeczeństwa konsumentów, nie może być kreowane półśrodkami. Innymi słowy, jedynie zatrudnienie projektanta, kompletna przebudowa i jednolita, zdyscyplinowana estetycznie stylistyka - działania z wielu względów niewyobrażalne w mieszkaniach wynajmowanych - daje możliwość konsumenckiej samorealizacji w zamieszkiwanym wnętrzu. Mieszkania estetyczne nie mogą być „niedomem” - przestrzenią tymczasowo zamieszkałą, jak mieszkanie w internacie, akademiku czy na migracji ${ }^{24}$.

Redakcja w celu podkreślenia (lub podniesienia) prestiżu omawianych mieszkań często sięga, nie zawsze słusznie, po określenie „apartament”25. Bez wątpienia

${ }^{23}$ M. Skowrońska, Jak u siebie. Zamieszkiwanie i komfort, Kraków 2015, s. 14.

24 Zob. M. Łukasiuk, M. Jewdokimow, Niedom: socjologiczna monografia mieszkań migracyjnych, Warszawa 2012.

25 Termin ten pojawia się nawet, gdy mieszkanie nie realizuje wszystkich cech apartamentu: „Prawdziwy apartament charakteryzuje się przede wszystkim prestiżową lokalizacją w śródmieściu lub innych atrakcyjnych dzielnicach, wysokością pomieszczeń około trzech metrów, zabezpieczeniem przed hałasem, klimatyzacją, wysokim standardem wykończenia, atrakcyjnym widokiem $\mathrm{z}$ okien i odpowiednim doświetleniem światłem dziennym. Minimalna powierzchnia 
mieszkania prezentowane w MjM są, jak na polskie mieszkalnictwo, duże. Wedle danych Głównego Urzędu Statystycznego w 2013 roku ${ }^{26}$ przeciętna wielkość mieszkania w mieście wojewódzkim wynosiła $64 \mathrm{~m}^{2} . \mathrm{W}$ analizowanych czasopismach pojedyncze osoby mieszkają w mieszkaniach 50-80-metrowych, pary zwykle wybierają metraże od 70 do 120 metrów, rodziny (najczęściej rodzice i jedno dziecko) mają apartamenty 90-120-metrowe lub mieszkają w domach do 220 metrów ${ }^{27}$. Są to mieszkania najczęściej położone w stolicy, sporadycznie w innych dużych polskich miastach — Łodzi, Katowicach, Olsztynie.

Kolejnym ważnym elementem narracji o mieszkaniach estetycznych w MjM są wykonane na zamówienie meble. Te niepowtarzalne, specjalnie zaprojektowane do danego wnętrza sprzęty stanowią opozycję wobec mebli dostępnych w sprzedaży masowej, a przez to budują prestiż wnętrza:

Stół w salonie ma $120 \mathrm{~cm}$ średnicy i stoi na jednej toczonej nodze. Można jednak powiększyć blat o kolejne $120 \mathrm{~cm}$ i dokręcić cztery nogi. Został wykonany na zamówienie. (nr 5, s. 22)

Zabudowa kuchenna oraz wbudowany regał zostały zaprojektowane przez architektkę Weronikę Steffen-Lotarską, a wykonane przez firmę Alfamebel. (nr 1, s. 26)

Redakcja wyróżnia także (za pomocą tekstu i zdjęć) dzieła współczesnego malarstwa polskiego zdobiące ściany mieszkań. To również cecha, która wpisuje bohaterów w szeregi klasy średniej. W większości wypadków jednak obrazy te traktowane są wyłącznie powierzchownie - jako odpowiednio dobrany kolorystyczny detal lub tematyczne uzupełnienie otoczenia:

Zdaniem Damiana akryl Elektryfikacja Krzysztofa Turlewicza znakomicie pasuje do mieszkania sąsiadującego z dworcem kolejowym. - Chciałem dokupić kolejny obraz z serii, ale okazało się, że już żadnego nie ma, wszystkie znalazły właścicieli. Sąsiada dla „drucików” wypatrzył u... optyka. - Poszedłem zamówić okulary, wyszedłem z obrazem olejnym Ściany Barbary Levittoux-Świderskiej. (nr 6, s. 20)

Ścianę zdobi wykonany na zamówienie obraz Sebastiana Hmielika. - Chciałem nawiązać do położenia domu, pól i łąk. Stąd prosty, horyzontalny podział kompozycji przypominający widok za oknem. (nr 2, s. 21)

W dwóch przypadkach jest mowa o kolekcjonerskim zacięciu gospodarzy:

powinna wynosić co najmniej sto metrów kwadratowych” - M. Arczyńska, Luksus na miarę polskiego konsumenta - strategie marketingowe na rynku nieruchomości mieszkaniowych, „Architektura. Czasopismo Techniczne" 2010, nr 6, s. 309.

${ }^{26}$ Raport Głównego Urzędu Statystycznego: Gospodarka mieszkaniowa w 2013 r., Warszawa 2014, http://stat.gov.pl/obszary-tematyczne/infrastruktura-komunalna-nieruchomosci/nieruchomosci-budynki-infrastruktura-komunalna/gospodarka-mieszkaniowa-w-2013-r-,7,9.html (dostęp: 23.10.2018).

${ }^{27} \mathrm{~W}$ zebranym materiale znalazłam tylko jeden artykuł opisujący mniejsze mieszkanie (o wielkości $37 \mathrm{~m}^{2}$ ). Jego zakup redakcja uzasadniała niezwykle korzystną, „wymarzoną” lokalizacją: „Alicja nie wyobrażała sobie funkcjonowania w przestrzeni mniejszej niż $50 \mathrm{~m}^{2}$. Agentka namówiła ją jednak na odwiedzenie mieszkania, które było mniejsze, ale w wymarzonej lokalizacji. W ciągu dwóch dni zapadła decyzja o kupnie" (nr 4, s. 32). 
Pies w wykonaniu Michała Torzeckiego to pierwszy wspólny zakup właścicieli do ich domowej kolekcji sztuki. (nr 2, s. 35$)^{28}$

Nad kanapą mieści się ekspozycja prac artystów z galerii artpower.pl. (nr 3, s. 20)

Jednak w drugim fragmencie kolekcja sztuki w domu jest związana z zawodem pani domu, która zajmuje się sprzedażą dzieł sztuki:

Obrazy to naturalny element naszego życia (nr 3, s. 21).

Warto również podkreślić, że współczesne malarstwo to jedyny aspekt „kultury wysokiej", który można znaleźć we wnętrzu mieszkania estetycznego. W analizowanym materiale nie ma mowy o plakatach, grafikach, które pojawiają się w warstwie wizualnej artykułu - są one podporządkowane przede wszystkim stylistycznej dyscyplinie wnętrza - mają zdobić, nie przekazywać. Również posiadane przez gospodarzy książki to w przekazie MjM „trudny” element mieszkania, niekonotujący pozytywnych wartości (czytania) i najczęściej skrywany:

biblioteczka ukryta została w szafie w korytarzu. (nr 5, s. 33)

szafę, która pełni również funkcję biblioteczki przykryto kotarą, miękkie fałdy malowniczo opadające ku podłodze podświetlono. (nr 3, s. 37).

W całym zebranym materiale tylko w jednym opisie mieszkania estetycznego książki są ważnym elementem zamieszkiwanej przestrzeni, choć nadawca podkreśla ich zalety również na poziomie estetycznym („ocieplają wnętrze”):

Ważną rolę w domu grają książki, które tak jak obrazy odzwierciedlają zainteresowania domowników i ocieplają wnętrze. (nr 3, s. 21)

W opowieściach o mieszkaniach estetycznych niewiele jest rozpoznawalnych dzieł modnych projektantów, redakcja akcentuje obecność każdego z tych „dizajnerskich" elementów:

Na ścianie przy umywalce i prysznicu jest - jak go nazywa właścicielka - mały „dizajnerski eksces”, czyli terakota marki Marazzi, imitująca pognieciony papier Origami. (nr 4, s. 40)

słynna wyciskarka do cytrusów projektu Starcka. (nr 6, s. 49)

lampa projektu Mateli Crasset. (nr 5, s. 22)

designerski fotel $[\ldots]$ na suficie lampy Chors. (nr 4, s. 54)

klasyk polskiego wzornictwa - fotel RM58. (nr 6, s. 18)

${ }^{28}$ Wyraziście obecna w analizowanym magazynie strategia manifestowania wysokiej pozycji społecznej za pomocą dzieł współczesnego malarstwa odpowiada szerszym praktykom społecznym: „Możliwości takie [nabywania dzieł sztuki - K.B.] ma, według dość swobodnych szacunków, około 1-2\% społeczeństwa i chociaż nie wszyscy oni wykazują zainteresowanie sztuką, to zazwyczaj stają się jej nabywcami na przykład ze względów prestiżowych. Świadome kolekcjonerstwo sztuki jest w tej grupie zjawiskiem sporadycznym" - P. Kisiel, Sztuka we współczesnym mieszkaniu, [w:] Co to znaczy mieszkać..., s. 126-127. 
Obecność tych przedmiotów w mieszkaniu jest wynikiem realizacji pomysłu projektanta aranżującego wnętrza - są kosztownym, ekskluzywnym, czasem zaskakującym formą, dopełnieniem projektu, świadczącym o zamożności właścicieli.

Można zauważyć, że zgodnie z widocznym w społeczeństwach konsumpcyjnych zjawiskiem „inflacji dóbr pozycyjnych"29 gromadzony przez gospodarzy mieszkań estetycznych sprzęt RTV i AGD przestaje być wyznacznikiem statusu społecznego jednostki. Obecna w każdym z prezentowanych mieszkań elektronika nie jest tematem chętnie podejmowanym przez redakcję MjM. Sytuacja zmienia się tylko, gdy charakterystyka danego przedmiotu może być potraktowana jako ciekawostka ubarwiająca opowieść o mieszkaniu:

W warstwie dźwiękochłonnej (pięć centymetrów wełny mineralnej chroni przed odgłosami z pionu kanalizacyjnego) powstała wnęka na telewizor. Całość pokrywa tapeta - przypomina pikowaną tkaninę, dopiero z bliska widać, że to grafika. (nr 1, s. 37)

Zakupem, który zainspirował nas do prowadzenia zdrowszego trybu życia, jest piekarnik parowy - mówią właściciele. A ponieważ nie chcieli rezygnować z klasycznego piekarnika, zamontowali obydwa. (nr 1, s. 52)

Sylwia zwraca nam uwagę na płytę indukcyjną typu piano a filo. Przez to, że jest idealnie zrównana z powierzchnią blatu, jej czyszczenie jest wyjątkowo łatwe, a ponieważ ma ten sam kolor co granit - prawie jej nie widać. (nr 4, s. 24)

\section{Jest idealnie! 30}

Właściciele mieszkań estetycznych zgodnie zapewniają czytelników MjM, że ich przestrzeń życiowa jest wygodna i piękna. Rzadko wspominany jest jakiś niedoskonały aspekt tych idealnych wnętrz. Oto te wyjątki:

Kuchnia została zmniejszona do minimum, stąd mała lodówka i zlew z jedną komorą. (nr 4, s. 34)

Chociaż właściciele lubią naturalne drewno, w urządzaniu łazienki przeważyły względy praktyczne i ekonomiczne. Meble są oklejone imitującym dębowe drewno laminatem, a podłogę pokrywają winylowe panele, niedrogie, łatwe w montażu i odporne na wilgoć. (nr 4, s. 84)

Jednak nawet jeśli bohaterowie przyznają się na łamach czasopisma do dokonania wnętrzarskiego kompromisu, wymuszonego ograniczonym budżetem lub niewielką ilością miejsca do zagospodarowania, tego fragmentu mieszkania czytelnik nie zobaczy na zdjęciu. Przykładowo, cytowany wyżej fragment o łazience wykończonej tanimi panelami obrazowany jest ujęciami wnętrza nieprzedstawiającymi podłogi - nawet pozująca w łazience pani domu jest (wyjątkowo!) zaprezentowana od kolan wzwyż.

${ }^{29}$ U. Jarecka, Luksus w szarej codzienności, Warszawa 2013, s. 100.

${ }^{30} \mathrm{MjM}, \mathrm{nr}$ 5, s. 26. 


\section{Zakończenie}

Celem opracowania było przedstawienie sposobów, za pomocą których magazyny wnętrzarskie - istotna część konsumenckiego systemu eksperckiego odpowiadają na pytanie: „Jak mieszkać?”. Jednak nie wystrój wnętrza jest w tym kontekście wiodącym wątkiem. Wygląd samego mieszkania jest podporządkowany prowadzonej przez nadawcę opowieści o mieszkańcach - przedstawicielach klasy średniej (lub aspirujących doń), realizujących obowiązujące, opisane powyżej, modele konsumpcji.

Warto również zauważyć, że poza naszkicowanymi konsumpcyjnymi wymogami zamieszkiwania analizowane mieszkania estetyczne obrazują także ważną zmianę społeczną ostatnich dekad w postrzeganiu przestrzeni mieszkalnej. Można ją określić mianem konsumpcyjnego egocentryzmu. Analizowany periodyk wypełniają opowieści o realizujących się w egzotycznych wyjazdach i dyscyplinach sportowych singlach i parach. W mieszkaniach estetycznych nie ma śladów tworzenia relacji z innymi ludźmi (nawet ze współmieszkańcami), nie ma dzieci. Piotr Korduba, opisując dominujący w PRL-u model urządzania mieszkań (nazwany przez niego tradycyjnym), zauważył, że w Polsce po drugiej wojnie światowej miejsce życia tworzyło relacje społeczne jednostki — dom był „miejscem socjalizacji i realizowania się człowieka, zapewniającym ciągłość i spójność narodu”31. Ważna była podkreślana we wnętrzu przynależność rodzinna $-\mathrm{z}$ pietyzmem zbierano meble z przeszłością („antyki”), obrazy, kilimy czy porcelanowe serwisy do herbaty. Doświadczenie wojny sprawiło, że przedmioty te niezmiernie rzadko były dziedziczone po przodkach, częściej kupowano na targach staroci i komisach, by później zaprezentować światu jako schedę „po dziadku”. W opisywanych na łamach „M jak Mieszkanie” wnętrzach przedmioty nie przypominają o rodzinnej przeszłości. Rygory społeczeństwa konsumpcyjnego uniemożliwiają opowieści o jakiekolwiek przeszłości - przypominającej o przemijaniu i nietrwałości życia ludzkiego. Charakteryzowane przestrzenie mieszkalne nie opowiadają także o podtrzymywanych więziach społecznych $\mathrm{z}$ teraźniejszości. $\mathrm{W}$ ujęciu analizowanego magazynu gospodarze mieszkań estetycznych żyją w przestrzeni wystylizowanej, higienicznej, pozbawionej śladów własnych doświadczeń i własnego przemijania. Innymi słowy, przestrzeni pozbawionej wszystkiego, co kłopotliwe, zbyt trudne i zbyt złożone dla społeczeństwa konsumentów.

${ }^{31}$ P. Korduba, Przymusowy kostium, „2+3D” 2014, nr 3, s. 112. Drugi wspomniany przez Kordubę model zamieszkania to mieszkanie socjalistyczne - pozbawione sfery prywatnej i intymnej - życie społeczne miało być realizowane kolektywnie: we wspólnej kuchni, jadalni, łaźni czy na zebraniach w świetlicy i domu kultury. 


\section{Bibliografia}

Arczyńska M., Luksus na miarę polskiego konsumenta - strategie marketingowe na rynku nieruchomości mieszkaniowych, „Architektura. Czasopismo Techniczne” 2010, nr 6.

Bauman Z., Płynna nowoczesność, przeł. T. Kunz, Kraków 2006.

Bielecka-Prus J., Wycieczka po pokoju nastolatki: praktyki prezentacji przestrzeni prywatnej w wideoblogach, [w:] Socjologia zamieszkiwania, red. M. Łukasiuk, M. Jewdokimow, Warszawa 2014.

Biskupska K., Mieszkanie wypetniło się światłem, czyli o (pozornej) wolności w mieszkaniu estetycznym, „Znaczenia. Kultura - komunikacja - społeczeństwo” 2015, nr 13.

Brosz M., (Za)mieszk(iw)anie. Przestrzeń konstruowana, [w:] Co to znaczy mieszkać. Szkice antropologiczne, red. G. Woroniecka, Warszawa 2007.

Dowgiałło B., Moda w mieszkaniu, [w:] Co to znaczy mieszkać. Szkice antropologiczne, red. G. Woroniecka, Warszawa 2007.

Giddens A., Nowoczesność i tożsamość, przeł. A. Szulżycka, Warszawa 2010.

Jacyno M., Mieszkanie i „moralna architektura” kultury indywidualizmu, [w:] Co to znaczy mieszkać. Szkice antropologiczne, red. G. Woroniecka, Warszawa 2007.

Jarecka U., Luksus w szarej codzienności. Społeczno-moralne konteksty konsumpcji, Warszawa 2013.

Kisiel P., Sztuka we wspótczesnym mieszkaniu, [w:] Co to znaczy mieszkać. Szkice antropologiczne, red. G. Woroniecka, Warszawa 2007.

Korduba P., Przymusowy kostium, „2+3D” 2014, nr 3.

Łukasiuk M., Jewdokimow M., Niedom: socjologiczna monografia mieszkań migracyjnych, Warszawa 2012.

Mistewicz E., Marketing narracyjny. Jak budować historie, które sprzedają, Gliwice 2011.

Piekot T., Dyskurs wiadomości prasowych, Kraków 2006.

Piwowarska A., Autentyczność przyciaga. Jak budować swoją markę na prawdziwym i porywającym przekazie?, Gliwice 2015.

Rancew-Sikora D., Dom estetyczny jako dom indywidualny, [w:] Co to znaczy mieszkać. Szkice antropologiczne, red. G. Woroniecka, Warszawa 2007.

Skowrońska M., Jak u siebie. Zamieszkiwanie i komfort, Kraków 2015.

Stemplewska-Żakowicz K., Koncepcje narracyjnej tożsamości. Od historii życia do dialogowego „ja”, [w:] Narracja jako sposób rozumienia świata, red. J. Trzebiński, Gdańsk 2002.

Wieczorkiewicz A., O wyobraźni kulinarnej i aporii jedzenia. Kultura uwikłana w konsumpcję, [w:] Terytoria smaku. Studia z antropologii i socjologii jedzenia, red. U. Jarecka, A. Wieczorkiewicz, Warszawa 2014.

Woroniecka G., Wstęp. Co to znaczy mieszkać, [w:] Co to znaczy mieszkać. Szkice antropologiczne, red. G. Woroniecka, Warszawa 2007.

\section{"She works in the corridor, writes on the walls and takes a bath among flowers", or images of consumer homes in the discourse of interior design magazines}

\section{Summary}

The article presents the requirements of a consumer society towards the living space of (ideal) consumers. The subject of the analysis are discursive constructions of apartments (at the level of text and image) present in the message of interior design magazines. Apartments defined in this way are referred to as aesthetic apartments. The main themes of the analysis conducted by the author are: the narrative of the message, the presentation of hosts as perfect consumers, indicators of "proper" consumption that are present in the living space and the process of individualization of consumer life in the created living space. 